\title{
Understanding the Education Philosophy and Its Implications
}

\author{
Chandra Dip Lamichhane \\ Lecturer, Nepal Commerce Campus
}

\begin{abstract}
Education is the process of facilitating learning, or the acquisition of knowledge, skills, values, beliefs, and habits. Education is the development of all those capabilities in which the individual which is enable him to control his environment and fulfillment his possibilities. It is a process of acquiring new habits, knowledge \& skill which together enables learners to do something that he/she could not do before. It is a mental activity by means of which skills, attitude, appreciation and ideas are acquired, resulting in modification of behaviors. The purpose of this article is to discussabout the philosophy, importance and implications of education processin our contemporary environment as well as the world. How the people acquire knowledge, ideas, and skills and utilize to those knowledge and ideas for the development and prosperity of humankind as well as the development of nation and the entire world is the main objective of this article.
\end{abstract}

Key word: Philosophy, Idealism, Realism, Netaurism, Pragmatism

\section{Introduction}

According to Socrates-"Education means bringing out of the idea of universal validity which is latent in the mind of every man".

According to Knowels(1995), education is the development of all those capabilities in which the individual which is enable him to control his environment and fulfillment his possibilities.

According to Mrunalini (2010), education is the process of changing behavior pattern of people acquisition of the art of utilization of knowledge and ideas.

Thus, the education is the process of facilitating learning, or the acquisition of knowledge, skills, values,beliefs, and habits. Education is the development of all those capabilities in which the individual which is enable him to control his environment and fulfillment his possibilities.

\section{Aims of Education}

Education is mostly planned and purposeful activity. It must have clear aims and objectives. An aim is pre-determined goal which inspires the individual to attain

$$
\sim 24 \sim
$$


it through appropriate activities. Educational aims are necessary in giving direction to educational activity. There are certain factors determining educational aims. They are-

Philosophy of life

Element of human nature

Religion

Political ideologies

Socioeconomic factors

Emerging problem of nation

Cultural factors

Exploration of knowledge and technology

Utilitarian aim- it is concerned with providing knowledge and skill required by the child for leading his day to day life. Fulfillment of this aim will enable him to make use of the knowledge and skill in a fruitful manner. It makes the education process a purposeful one and depicts the relationship between education and life. To enhance or update the knowledge, student should be given enough opportunities for widening and deepening their knowledge through exploration. Encouraging student to express their own ideas in their own words will help them to acquire knowledge.

Vocational aim- education should prepare the child to earn his livelihood so that he can lead a productive life in the society. Dignity of labor and respect to the labor have to be developed or inculcated by means of education.

Social aim- every individual is considered as a productive member of the society. Though education the individual child should be provided with the required assistance to become a useful member of the society, irrespective of the socioeconomic status. Keeping this aim in mind, educationists have to help learners to develop a healthy, purposeful, productive, exploratory and controlling adjustment with the environment. Society is the result of the interrelations of individuals. It consists of big and small groups and there are subgroups within each group. Education helps the child to understand this interrelation of individuals and possibilities of various groups. By the way of education student should realize the importance of social values like justice, fair play, healthy competition, harmony, etc. in short, education instill a sense of obligation and loyalty towards the community and its needs. By means of social aim, education gives direction in the development of the society.

Intellectual aim- it is essential for acquiring knowledge, thinking, reasoning, judgment and generalization. Education provides enough opportunities to develop the innate intellectual capacity of the student development of intelligence through education will enable the child to lead an independent life with confidence.

Citizenship- it helps the child to grow as productive citizens by following the social and moral standards set by the society. Education motivates the child to perform his duties and responsibilities as citizen, for the welfare of the society. All countries in general and democratic countries in particular have to upload this aim of education.

Physical health and wellbeing- education prepare the child to lead a healthy life through providing the knowledge required for a healthy living and helping him to develop a positive attitude towards health. Education should also help child to develop 
a health conscience and respect towards his or her own health.

Character development- character development as a supreme aim of education. Education assists the child to develop certain human values, attitudes, and habits which are essential for building a desirable character.

Mental development- moral values like honesty, truthfulness, justice, goodness, purity, courage, dutifulness, punctuality, self-confidence, discrimination between good and bad, observation rules, beliefs in systematic organization, etc. are inculcated through education. These qualities contribute to the development of morality and sound character.

Cultural development- by under -going education child becomes cultures and civilized. Cultural development is manifested through the development of an esthetic sense and respect for others culture.

Education for leisure- leisure is the time meant for enjoyment and recreation. Leisure plays an important role in recharging our depleted energy levels. Leisure time should be utilized in such a way that the individual as well as the society should benefit from it.

Self-realization- what we are is God's gift to us and what we become is our gift to God. Child is born with tremendous potentials and the equipping him to utilize the identified.

Mental and emotional development- in this fast changing world, good mental health is a cope with the changing lifestyles and societal needs. Education should train the child by giving adequate opportunities for mental and emotional development. Nowadays, lot of research is taking place to gather more information regarding the role of emotional development on education and life. Recent studies show that emotional development is essential to conduct proper self- appraisal, control unhealthy emotions, develop an aim in life, attain emotional maturity, etc.

Autonomous development- an individual child has to develop in total by seeking assistance and direction extended life situations and include development of personality, character, leadership, maturity, mental health, physique and intelligence. Percynunn recommends formal education for autonomous development. She believes that activity oriented curriculum enriched with varied learning activities, teaching method, facilities for guidance and counseling, discipline and proper direction will cher should make sure that students are learning as result of contribute to autonomous development.

Self-education aim- as education is considered as a life long process, I should prepare the child to adopt a proactive role towards the learning process. Education has to properly harness the natural curiosity and urge present in the child while imparting knowledge. The aim is gaining importance in this era of knowledge explosion where students are expected to take a leading role in the teaching-learning process than the teacher. Teachers should make sure that students are learning as a result of the internal motivation rather than a reaction to the compulsion exerted by others.

International understanding- education is a universal process and it helps in creating universal understanding. The progress we achieved in the field of education is the result of the combined efforts of people from different countries, the scholars 
of all periods, the followers of all religions and member of all the races. Education is the common heritage of mankind and it is not an exclusive property of any particular nation, race or community. All educationists, irrespective of their caste, color and creed worked devotedly towards the development of education.

Harmonious development- ultimately the overall aim of education is to ensure harmonious development through the achievement of the above mentioned aims. Harmonious development will enable the child to deal effectively with the problem and uncertainties of life.

\section{Philosophy of Education and Its Implications}

Philosophy is the study of the principles of human behavior and reasoning about we really know of the human behavior and reasoning about we really know of the universe and ourselves. It means, philosophy is that through which man tries to understand him and the world in which he/she views. Major system of philosophy of education are:

Idealism- it is oldest system of philosophy known to man. Its origin goes back to ancient India in the east, and to Plato in the west. Its basic viewpoint stresses the human spirit as the most important element in life.

The human spirit is most elements in life, the universe is essentially nonmaterial in its ultimate nature. Idealism is concerned with supremacy of mind and self, and views man and universe in terms of spirit or mind. Matter or objective may be the projection or creation of mind, but ultimately real is the idea behind it. The physical world is ephemeral and can be changed through the ideas or imagination of man. Plato, the greatest philosopher of all ages, claimed that the ultimate reality consists of ideas. Plato and his teacher Socrates conceived ideas as the basis of their philosophy.

Socrates, an idealistic philosopher placed importance on question-answer and dialogue as the method of acquiring information or gaining knowledge whereas Plato emphasized on logical reasoning as the method of gaining knowledge.

\section{Educational implications of idealism}

Idealism considers student as an individuals with inner potentials. Education should help the student to realize these potentials. Curriculum should consist of those knowledge and experiences which help the student to attained development. The teacher should impart essentials of knowledge and assist to develop moral and aesthetic values in the child. As said earlier, idealism stresses more on the spiritual development of the child.

Naturalism - it is oldest philosophy in western world. The naturalists view the world that we live in is made up of the matters, and believe that the material world, the world of nature, is the real world. In other word nature is the source of knowledge. The human life is the part of nature and is therefore controlled by external laws of nature. In fact, the essence of all things is nature.

The universe and man are the results of physical, mechanical and biological forces acting upon them, which is called natural laws. The process of growth and development in man was the result of force of energy prevailed in nature. Man's natural endowment, 
including his instincts and emotion are the guiding force of all his conducts.

The theory of struggle put forward by Charles Darwin implicates that the aim of education is to equip individual to struggle for existence and thus to ensure his survival. It should help the learner to adjust physically and mentally to ever changing circumstances of life. Education should aim at developing the child joyful, rational, balanced, purposeful and mature person in order for him to survive.

\section{Educational implications of naturalism}

Applied to education, naturalism considers child as a gift of nature with potentialities for natural growth according to laws of nature. The child is an active individual capable of self- development. The aim of education is to develop the child as healthy and active personality in a natural setting. The growth process must be natural and real without any interference from outside. The powers of the child should be developed in natural ways by allowing the child to freely interact with the nature. The curriculum should provide concrete and real experiences in a natural context. The child should be exposed to a variety of sensory and physical activities. The child learns by interacting with nature. Morality and character learned directly with the help of natural consequences. Discipline is developed as a result of consequences of behavior of child. The teacher plays the role of guiding the child learning from nature.

\section{Realism}

The term 'realism', derived from the world 'real', finds its origin in Greek word: 'Res " which means object. The realistic propagates that we see and experience around us is the truth. The realists propagates the world as nature rather than supernatural. The realistic believe that the physical universe is operated by natural laws. Aristotle (384-322 B.C.), a Greek philosopher is generally recognized as the father of realism.

The purpose of education was to prepare for complete living, the Realists believed. Education should equip the learners with the knowledge and skills that are needed to understand and master his physical environment so that he can live a happy and comfortable life.

\section{Educational implications of realism}

Realism considers the child as a dynamic and growing entity ready to face reality of life. The laws of nature control the child. The aim of education is to prepare the child to face. Hence the realist suggest that the curriculum should be broad based and include variety of subjects, especially science subjects. While selecting the subjects, the learner's background and social demand should be considered. Realism suggests objective methods of teaching. Importance must be given to observation, experimentation and activities. According to realism discipline is developed by controlling environment.

\section{Pragmatism}

Pragmatism adopt a midway between idealism and naturalism. The word pragmatism derived from Greek word "pragma" means action. Pragmatism is otherwise known as instrumentalism or functionalism. Since emphasis was given to learning by 
doing and learning by experience, it is also called experimentalism

According to Ross, pragmatism is essentially a human philosophy maintaining that man creates his own values in course of activity, that reality is still in making and awaits its part of completion from the future. This definition emphasis on creation through continuous activity and states that certain values are essential for growth and development of individual.

\section{Educational implication of pragmatism}

Pragmatism trend in education is known as progressivism in education and the school based on programmatic ideas was known as progressive school. Pragmatism considers the learner as growing biological and social being ready to adjust to the environmental demands. The aim of education should be to prepare the child to become an effective member of community. It should also try to develop competencies in the child. Hence the curriculum should include those subjects and experience which are suitable to the child's interest and needs. The curriculum should be develop an attitude of inquiry, facilitate artistic expression, encourage constructiveness and sustain interest in the child. Deway advocates "learning by doing", which encourages the child to learn trough activities. Deway considers discipline as a function of the teaching- learning situation. If the learning is made joyful and interesting, there is no need to use external rewards and punishments. A pragmatic teacher helps in the ready-made forms, teacher should encourage the learner through active interaction with the learning situation.

\section{References}

Agarwal, J.C.(1996). Teachers and education in a developing society. New Delhi: Vikas Publishing house Pvt. Ltd.

Arulsamy, S. (2010). Educational Innovations and management. New Delhi: Neelkamal Publishers.

Cohen,L., Menion, L. \&Morrison, K.(2005). Research methods in education. New York: Taylor \& Francis e-Library.

Hadhwa, S. (2006). Teaching and learning methodology in higher education. New Delhi: Sarup and Sons publications.

Knowels,M. (1995). Self directed learning: A guide for learners and teachers. New York: Association press.

Mrunalini, T. (2010). Educational evaluation. New Delhi: Neelkamal Publishers. 